Prepared in cooperation with the Central Utah Water Conservancy District

\title{
Streamflow Investigations on a Reach of Hobble Creek Near Springville, Utah
}

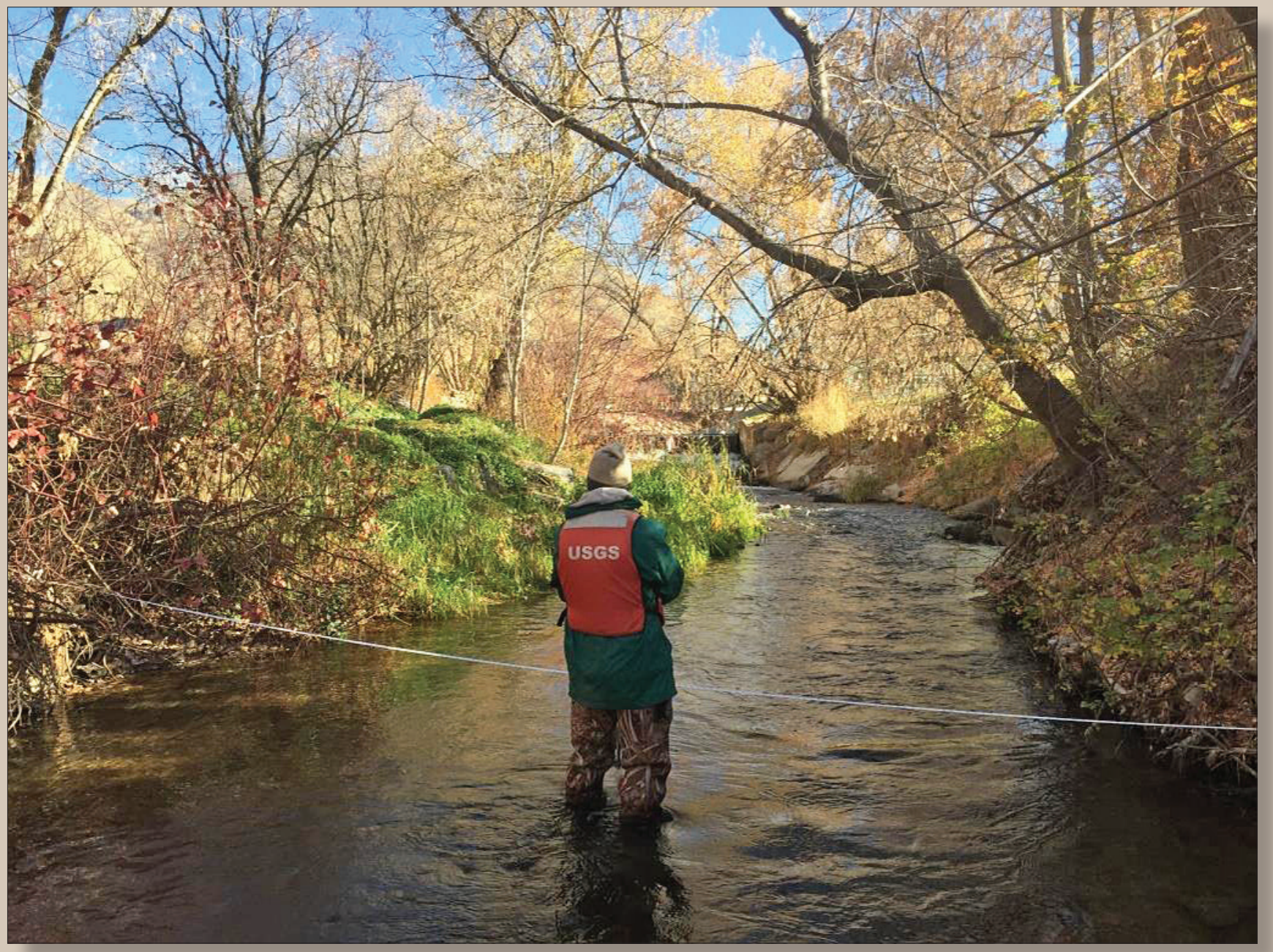

Open-File Report 2017-1084 
Cover photograph: Martel Fisher measuring streamflow in Hobble Creek, near Springville, Utah, looking upstream.

Photo by Steven Gerner, U.S. Geological Survey, November 8, 2016. 


\section{Streamflow Investigations on a Reach of Hobble Creek Near Springville, Utah}

By Steven J. Gerner

Prepared in cooperation with the Central Utah Water Conservancy District

Open-File Report 2017-1084 


\title{
U.S. Department of the Interior \\ RYAN K. ZINKE, Secretary
}

\section{U.S. Geological Survey William H. Werkheiser, Acting Director}

\author{
U.S. Geological Survey, Reston, Virginia: 2017
}

For more information on the USGS - the Federal source for science about the Earth, its natural and living resources, natural hazards, and the environment—visit http://www.usgs.gov or call 1-888-ASK-USGS.

For an overview of USGS information products, including maps, imagery, and publications, visit http://store.usgs.gov/.

Any use of trade, firm, or product names is for descriptive purposes only and does not imply endorsement by the U.S. Government.

Although this information product, for the most part, is in the public domain, it also may contain copyrighted materials as noted in the text. Permission to reproduce copyrighted items must be secured from the copyright owner.

Suggested citation:

Gerner, S.J., 2017, Streamflow investigations on a reach of Hobble Creek near Springville, Utah: U.S. Geological Survey Open-File Report 2017-1084, 9 p., https://doi.org/10.3133/ofr20171084.

ISSN 2331-1258 (online) 


\section{Contents}

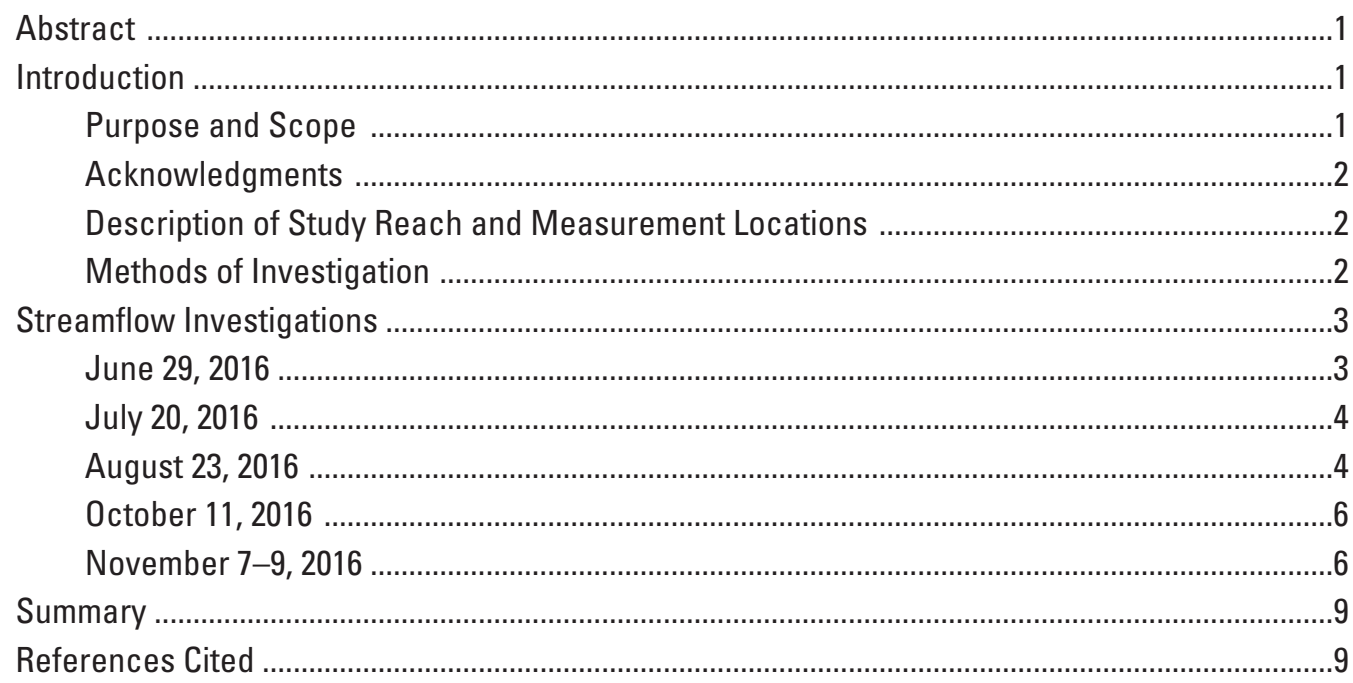

\section{Figures}

1. Map showing Hobble Creek study area and location of discharge measurement sites .......2

2. Graph showing discharge in Hobble Creek at sites $\mathrm{HC} 3$ and $\mathrm{HC6}$, in relation to pulse from Mapleton-Springville Lateral pipeline, August 23, 2016 .............................................5

3. Graph showing discharge in Hobble Creek at sites $\mathrm{HC} 3, \mathrm{HC} 6$, and $\mathrm{HC} 8$ in relation to pulse from Mapleton-Springville Lateral pipeline, November 7-9, 2016

\section{,} 2

\section{3}

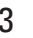

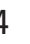

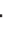
6 6 9 9 .

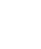

3

,

.

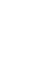




\section{Conversion Factors and Datums}

Inch/Pound to International System of Units

\begin{tabular}{lcl}
\hline \multicolumn{1}{c}{ Multiply } & By & \multicolumn{1}{c}{ To obtain } \\
\hline mile (mi) & Length & \\
\hline \multicolumn{3}{l}{ Volume } \\
\hline acre-foot (acre-ft) & 1.609 & kilometer $(\mathrm{km})$ \\
acre-foot (acre-ft) & 1,233 & cubic meter $\left(\mathrm{m}^{3}\right)$ \\
& 0.001233 & cubic hectometer $\left(\mathrm{hm}^{3}\right)$ \\
\hline cubic foot per second $\left(\mathrm{ft}^{3} / \mathrm{s}\right)$ & Flow rate & \\
\hline
\end{tabular}

Horizontal coordinate information is referenced to the North American Datum of 1983 (NAD 83).

Vertical coordinate information is referenced to the North American Vertical Datum of 1988 (NAVD 88).

Elevation, as used in this report, refers to distance above sea level. 


\title{
Streamflow Investigations on a Reach of Hobble Creek Near Springville, Utah
}

\author{
By Steven J. Gerner
}

\section{Abstract}

The Central Utah Water Conservancy District (CUWCD) is proposing to deliver supplemental flow to Hobble Creek from Strawberry Reservoir through the Mapleton-Springville Lateral pipeline. A substantial portion of the supplemental water is intended to benefit June Sucker recovery and other fish and wildlife along Hobble Creek. The objective of this study was to determine gains or losses of water in a section of Hobble Creek between the Island Dam and the Swenson Dam (the primary study reach) during different seasons and flow conditions.

Paired measurements of flow in Hobble Creek were made during June to November 2016, at sites bracketing the primary study reach from site $\mathrm{HC} 3$ to HC6. These measurements showed increased streamflow in this reach that ranged from 6.1 cubic feet per second ( $\mathrm{ft}^{3} / \mathrm{s}$ ) to $9.3 \mathrm{ft}^{3} / \mathrm{s}$. During August and November, two sets of measurements were made at several locations along the study reach to document baseline conditions, and then an additional amount of water (a pulse of about $9-10 \mathrm{ft}^{3} / \mathrm{s}$ ) from Strawberry Reservoir through the Mapleton-Springville Lateral pipeline, was added to the reach. During the August 23 measurements, the average change at the upstream site $(\mathrm{HC} 3)$ relative to the pulse was $9.3 \mathrm{ft}^{3} / \mathrm{s}$, and the average change at the downstream site (HC6) was about $8.4 \mathrm{ft}^{3} / \mathrm{s}$, leaving about $0.9 \mathrm{ft}^{3} / \mathrm{s}$ of the additional water unaccounted for at site HC6. However, there was no significant difference between the net streamflow volume at sites $\mathrm{HC} 3$ and HC6 associated with the pulse that would indicate water was being lost. During the November 7-9 streamflow measurements, the average change in discharge at site $\mathrm{HC} 3$ relative to an increase in flow from the Mapleton-Springville Lateral pipeline (the pulse) was $9.6 \mathrm{ft}^{3} / \mathrm{s}$, and the average change at site HC6 was about $9.8 \mathrm{ft}^{3} / \mathrm{s}$. On the basis of these measurements it appears that the entire amount of the pulse added to the stream at site HC3 was accounted for at site HC6. Additionally, there was no significant difference between the net streamflow volume at sites $\mathrm{HC} 3$ and $\mathrm{HC} 8$ associated with the pulse that would indicate water was being lost.

\section{Introduction}

The Central Utah Water Conservancy District (CUWCD) is proposing to deliver supplemental water to Hobble Creek from Strawberry Reservoir through the Mapleton-Springville Lateral pipeline. A substantial portion of the supplemental water is intended to benefit June Sucker recovery and other fish and wildlife along Hobble Creek as outlined in Lower Hobble Creek Ecosystem Flow Recommendations (Utah Reclamation Mitigation and Conservation Commission, 2009). Of interest to CUWCD is the fate of supplemental water delivered to Hobble Creek through the Mapleton-Springville Lateral pipeline. Because this water is intended to support instream flows in the lower reach of Hobble Creek, it is essential to know if the additional water would transit the study reach or might be diverted to irrigation systems or lost to streambed seepage.

\section{Purpose and Scope}

This report presents the results of a study to measure and compare streamflow at multiple sites in a reach of Hobble Creek between the Island Dam and the Swenson Dam during different seasons and flow conditions. A subset of measurements was made to evaluate the fate of a supplemental inflow, or pulse, of water introduced to Hobble Creek from the Mapleton-Springville Lateral pipeline.

During June to November 2016, five sets of streamflow measurements were made at multiple locations along the study reach. An analysis of these measurements was made to determine streamflow gains or losses along the study reach. Possible sources of streamflow gains included surface inflow from springs and ditches, irrigation diversions, transbasin diversions, and groundwater seepage. Possible streamflow losses included streambed seepage, irrigation diversions, and streambank storage. Determination of the amount of individual streamflow gain or loss associated with these and other components was beyond the scope of this study. 


\section{Acknowledgments}

The author thanks the following individuals and organizations for their assistance, insight, and cooperation: Tom Stetson, Springville Irrigation Company; Tyson Bartlett, Springville City; and Mark Breitenbach and Jackson Crofts, Central Utah Water Conservancy District.

\section{Description of Study Reach and Measurement Locations}

Hobble Creek originates to the east of Springville, Utah, in the Wasatch Mountains at an elevation of approximately 9,000 feet. The principal study area, defined as the portion of the creek between the Island Dam and the Swenson Dam (fig. 1), begins about 3.8 miles (mi) downstream of the confluence of the Right and Left Forks of Hobble Creek. Site HC3 is immediately downstream of the Mapleton-Springville Lateral pipeline and is the principal monitoring location for flows entering the study reach. Site HC6 is immediately upstream of the Swenson Dam and is the principal location for monitoring flows near the lower end of the study reach. To provide supplemental data, discharge measurements were made at other sites along Hobble Creek (table 1) within and outside the principal study reach.

The Hobble Creek drainage, in the vicinity of the study reach, is bounded on the south by the Mapleton Bench, which is underlain by a continuous layer of clay. This clay layer isolates the unconfined groundwater system from the deeper basin-fill aquifer, which results in springflow and groundwater discharge to Hobble Creek (Brooks and Stolp, 1995).

\section{Methods of Investigation}

Five sets of instantaneous streamflow measurements in Hobble Creek were made at the upstream (site HC3) and downstream (site HC6) ends of the principal study reach (fig. 1; table 2) to determine total changes in flow during early summer, midsummer and fall, and during irrigation and nonirrigation seasons. During August and November, additional measurements were made at several locations along the study reach to document baseline conditions, and then a pulse of about 9-10 cubic feet per second $\left(\mathrm{ft}^{3} / \mathrm{s}\right)$, designed to simulate the supplemental water proposed by CUWCD from Strawberry Reservoir through the Mapleton-Springville Lateral

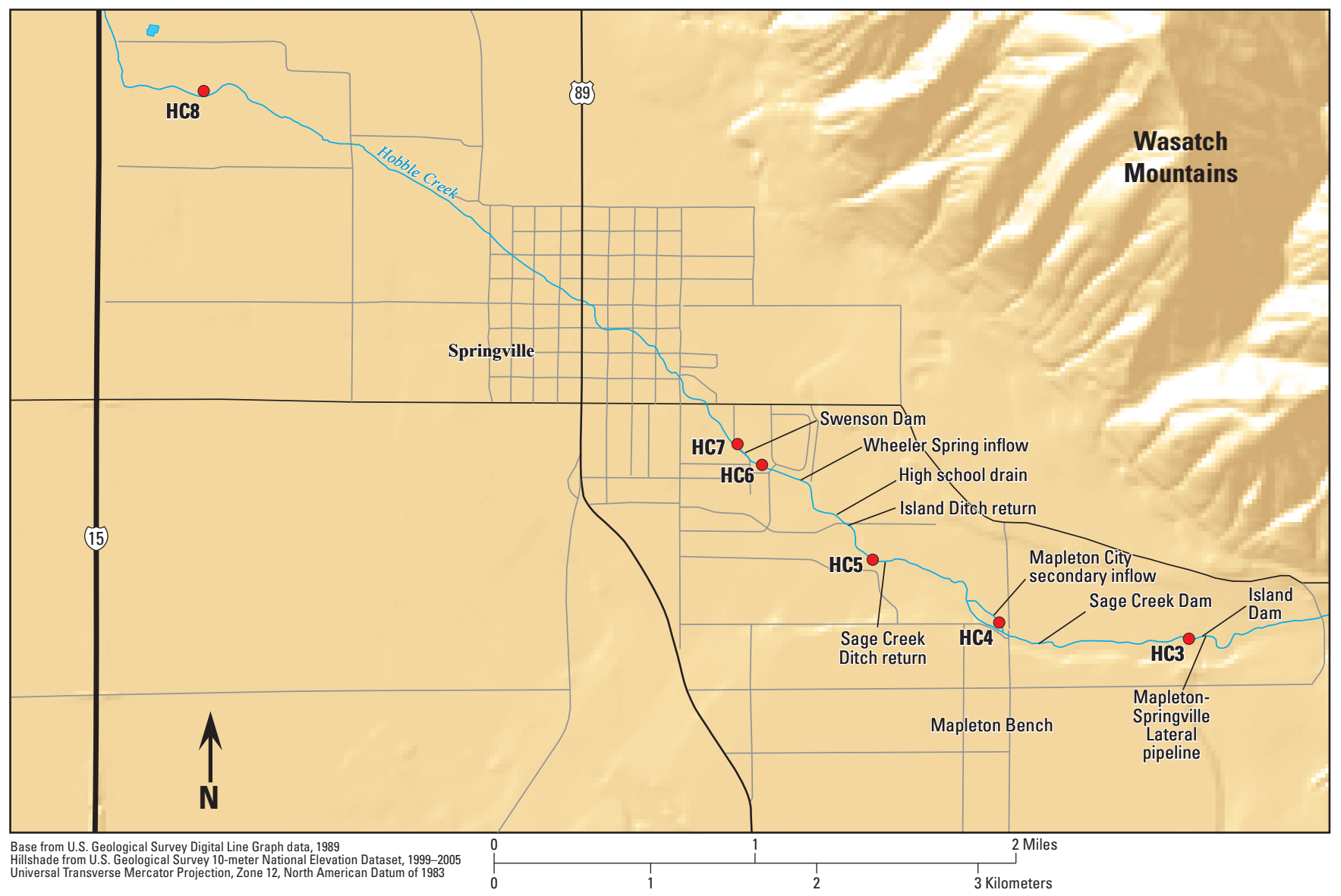

Figure 1. Hobble Creek study area and location of discharge measurement sites. Streamflow is from southeast to northwest. 
Table 1. Site names and identifiers, and distance downstream from the Mapleton-Springville Lateral pipeline for sites along Hobble Creek, near Springville, Utah.

[-, not applicable; HC, Hobble Creek; UT, Utah]

\begin{tabular}{|c|c|c|c|c|}
\hline Site name & Site number & Site identifier & Measurement site & $\begin{array}{l}\text { Distance downstream } \\
\text { from Mapleton-Springville } \\
\text { Lateral pipeline inflow, } \\
\text { in miles }\end{array}$ \\
\hline Mapleton-Springville Lateral pipeline & - & - & no & 0.00 \\
\hline Island Dam & - & - & no & 0.01 \\
\hline Hobble Creek at Witney Lane & 400852111335301 & $\mathrm{HC} 3$ & yes & 0.03 \\
\hline Sage Creek Dam & - & - & no & 0.89 \\
\hline Hobble Creek at 1700 East & 400854111344601 & $\mathrm{HC} 4$ & yes & 1.07 \\
\hline Hobble Creek at 1200 East & 400908111351901 & $\mathrm{HC} 5$ & yes & 1.93 \\
\hline Hobble Creek at 800 East & 400927111354501 & HC6 & yes & 2.70 \\
\hline Swenson Dam & - & - & no & 2.84 \\
\hline Hobble Creek at Averett Ave & 400931111355701 & $\mathrm{HC} 7$ & yes & 2.94 \\
\hline Hobble Creek at Springville, UT & 10153100 & $\mathrm{HC} 8$ & yes & 6.40 \\
\hline
\end{tabular}

pipeline, was added to the reach. Subsequent measurements were made throughout the reach to quantify gains and losses related to the pulse. Prior to each set of measurements, water managers were contacted and asked to maintain stable gate settings at inflows and outflows. Because of the complexity of the system and the number of governing entities involved, complete stability was rarely achieved.

Discharge measurements were made with acoustic Doppler velocimeters (ADVs) using standard methods of the U.S. Geological Survey (USGS) described in Turnipseed and Sauer (2010). Multiple measurements were generally made at each site during each visit to provide sufficient data to evaluate the accuracy of measurements. To reduce bias associated with the equipment or technique of individual technicians, concurrent measurements were often made by different personnel using different meters. Measurements were entered into the USGS National Water Information System (NWIS) database, and these data were retrieved from this system for analysis and presentation in this report (U.S. Geological Survey, 2017).

\section{Streamflow Investigations}

Paired measurements of flow in Hobble Creek at sites HC3 and HC6 consistently showed gains in streamflow between these sites. Five sets of paired measurements made from June to November 2016 show these gains ranged from $6.1 \mathrm{ft}^{3} / \mathrm{s}$ to $9.3 \mathrm{ft}^{3} / \mathrm{s}$ (table 2). Gains in flow in this reach are generally attributed to inflow from springs, drains, and dispersed groundwater discharge; however, during the non-irrigation season additional water is often discharged from the Mapleton City secondary system into Hobble Creek at site HC4. This was the case during the October and November measurements. During the October 11 measurements, the Mapleton City secondary system discharged about $3 \mathrm{ft}^{3} / \mathrm{s}$ to Hobble Creek (Mark Breitenbach, Central Utah Water Conservancy
District, written commun., 2016), and the estimated observed discharge from Wheeler Spring was about the same, hence, the larger $\left(9.3 \mathrm{ft}^{3} / \mathrm{s}\right)$ gain in flow along the study reach. During the November measurements, the Mapleton City secondary system discharged about $3.3 \mathrm{ft}^{3} / \mathrm{s}$ to Hobble Creek, but Wheeler Spring was discharging an estimated $0.2 \mathrm{ft}^{3} / \mathrm{s}$ to the study reach.

Streamflow was measured at sites HC3 and HC6 on June 29 , July 20, and October 10, to determine flow differences, and additional measurements were made at selected inflow sites. Because of the amount of water being diverted from Hobble Creek, these measurements are useful for observing net changes in flow along the study reach but lack sufficient information to quantify the amount of gain or loss from the stream channel, if any, that is occurring. Measurements made during August 23 and November 7-9 incorporated an experimental increase in flow (or pulse) that was used to investigate changes in gain or loss that might occur with supplemental water in the creek. Specifically, about 9-10 $\mathrm{ft}^{3} / \mathrm{s}$ of additional water was introduced to Hobble Creek through the Mapleton-Springville Lateral pipeline. Discharge measurements were made prior to, during, and after this pulse to document changes in streamflow relative to the pulse.

\section{June 29, 2016}

Discharge measurements were made in Hobble Creek at Witney Lane and at 800 East (sites HC3 and HC6, respectively) in Springville. Two discharge measurements made at site $\mathrm{HC} 3$ averaged $12.1 \mathrm{ft}^{3} / \mathrm{s}$, while two measurements made at site $\mathrm{HC} 6$ averaged $18.4 \mathrm{ft}^{3} / \mathrm{s}$ (table 2). Measurements at sites $\mathrm{HC} 3$ and HC6 showed an increase in flow of $6.3 \mathrm{ft}^{3} / \mathrm{s}$ along the study reach. Springs along the reach (including $2.8 \mathrm{ft}^{3} / \mathrm{s}$ from Wheeler Spring) accounted for most of the increase in flow. 


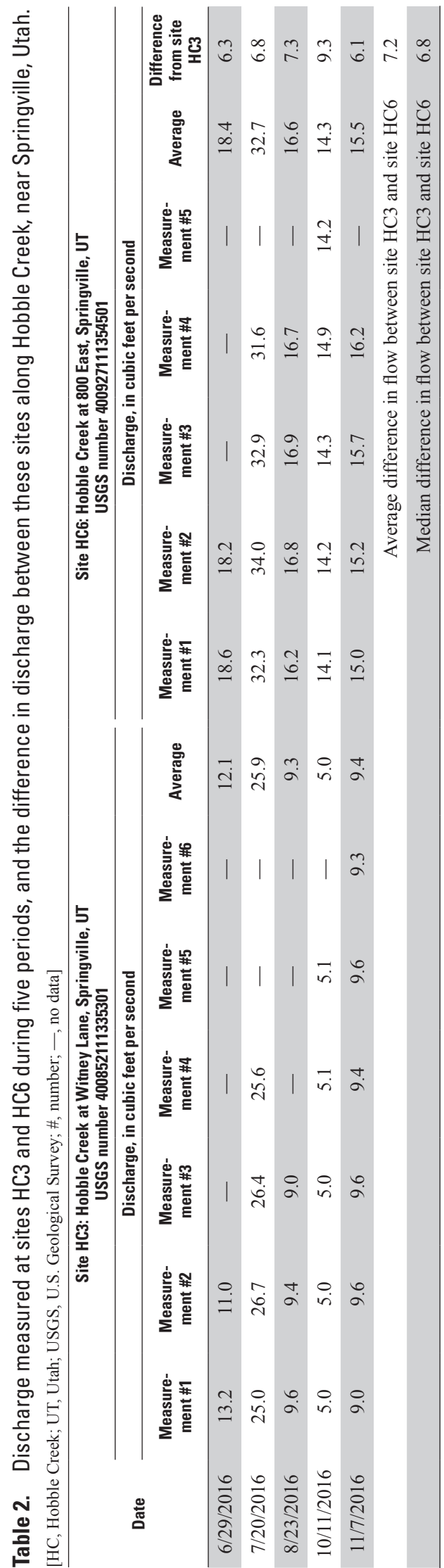

\section{July 20, 2016}

Discharge measurements were made in Hobble Creek at sites HC3 and HC6. Four discharge measurements were made at site $\mathrm{HC} 3$ under steady-stage conditions, with an average discharge of $25.9 \mathrm{ft}^{3} / \mathrm{s}$. Four measurements were made at site HC6 during which the stream stage was declining slightly; the average of the four measurements was $32.7 \mathrm{ft}^{3} / \mathrm{s}$. Measurements at sites HC3 and HC6 showed an average increase in flow of $6.8 \mathrm{ft}^{3} / \mathrm{s}$ along the study reach (table 2 ).

\section{August 23, 2016}

Measurements made in Hobble Creek on August 23 included a planned increase in streamflow (a pulse) of approximately $9-10 \mathrm{ft}^{3} / \mathrm{s}$ from the Mapleton-Springville Lateral pipeline. Initial measurements made at the head and tail of the primary study reach (sites $\mathrm{HC} 3$ and $\mathrm{HC} 6$, respectively) prior to the pulse showed an average flow of $9.3 \mathrm{ft}^{3} / \mathrm{s}$ at site $\mathrm{HC} 3$, and an average flow of $16.6 \mathrm{ft}^{3} / \mathrm{s}$ at site HC6 (table 3; fig. 2). After the pulse was initiated at 10:30 a.m., subsequent measurements showed an average discharge of $18.9 \mathrm{ft}^{3} / \mathrm{s}$ at site $\mathrm{HC} 3$, or an average increase in flow of $9.6 \mathrm{ft}^{3} / \mathrm{s}$. Discharge measured at site HC6 during the pulse averaged $24.7 \mathrm{ft}^{3} / \mathrm{s}$, or an average increase in flow of $8.1 \mathrm{ft}^{3} / \mathrm{s}$. The pulse was terminated at 1:00 p.m., and subsequent measurements showed a discharge of $9.9 \mathrm{ft}^{3} / \mathrm{s}$ at site $\mathrm{HC} 3$, a decrease of $9 \mathrm{ft}^{3} / \mathrm{s}$ from the pulse flow. Average discharge measured at site HC6 following termination of the pulse was $16.1 \mathrm{ft}^{3} / \mathrm{s}$, a decrease of $8.6 \mathrm{ft}^{3} / \mathrm{s}$ from the pulse flow. The average change at site $\mathrm{HC} 3$ relative to the pulse was $9.3 \mathrm{ft}^{3} / \mathrm{s}$, while the average change at site HC6 was about $8.4 \mathrm{ft}^{3} / \mathrm{s}$. On the basis of these instantaneous measurements, it appears that about $0.9 \mathrm{ft}^{3} / \mathrm{s}$ of the flow measured at site HC3 during the pulse was not accounted for at site HC6.

During the August investigation stream stage was monitored and recorded at 15-minute intervals at sites $\mathrm{HC} 3$ and HC6. A stage/discharge relation was developed using instantaneous measurements of stage and discharge (data available on NWISWeb at https://waterdata.usgs.gov/ut/nwis/measurements), which was then used to calculate the discharge shown on figure 2. A baseline discharge was determined from values prior to and after the pulse. This baseline discharge was subtracted from the total discharge during the pulse, and the net streamflow volume associated with the pulse (shown as the shaded areas on figure 2) was determined. For the August investigation the theoretical streamflow volume associated with the pulse was 1.92 acre-feet (acre-ft) $\left(9.3 \mathrm{ft}^{3} / \mathrm{s}\right.$ for 2.5 hours). The calculated value for streamflow volume associated with the pulse at site $\mathrm{HC} 3$ was 1.89 acre-ft, and the calculated value at site HC6 was 1.92 acre-ft (table 3). The calculated values are 98 and 100 percent, respectively, of the theoretical value. Because the calculations of discharge used in this study are generally plus or minus 5 percent, there is no significant difference between the theoretical streamflow volume and the calculated streamflow volume at sites HC3 and HC6 associated with the pulse that would indicate water was being lost. 

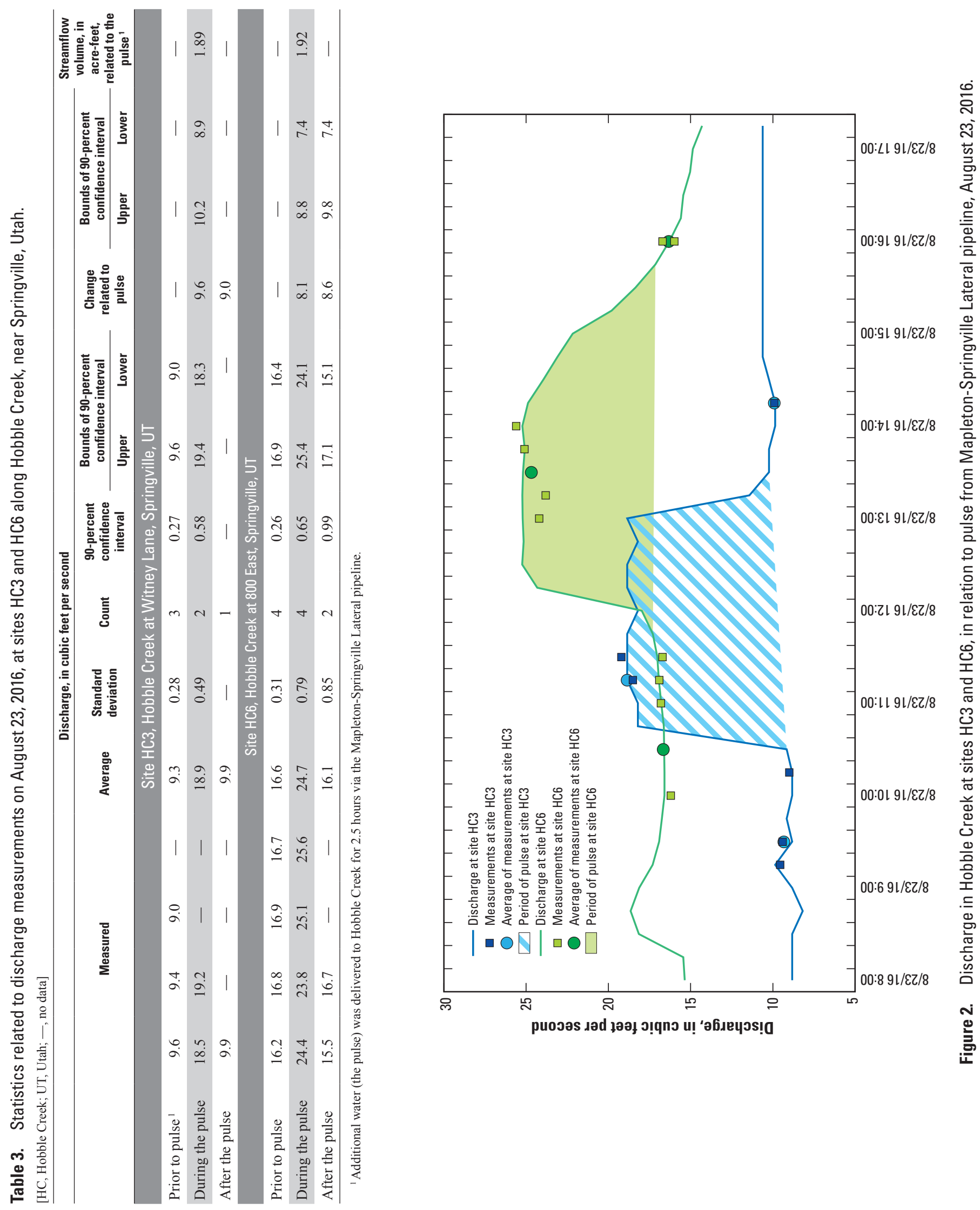
During the investigation, water managers maintained settings on inflow and outflow diversion structures as much as possible, but increased head in diversion pools and in diversion boxes could result in increased flow through the diversion system. For example, the discharge at the Sage Creek Ditch weir increased from $4.3 \mathrm{ft}^{3} / \mathrm{s}$ prior to the pulse to $4.8 \mathrm{ft}^{3} / \mathrm{s} \mathrm{dur-}$ ing the pulse. It was noted that a diversion box downstream of the weir had filled and water may have been entering a secondary ditch. Water associated with the pulse that was diverted to the irrigation system has several opportunities to return to the stream. Because water diverted to the irrigation system and subsequently returned to the stream could venture along a longer flow path, this could account for some of the differences in discharge measurements at sites $\mathrm{HC} 3$ and HC6. Additionally, the timing of the pulse was probably too short to determine longer-term gains and losses in the creek associated with bank storage. The banks of the creek likely did not have time to reach a steady-state condition, and differences in discharge measurements at sites HC3 and HC6 during the pulse may be attributable, in part, to bank storage.

Because of substantial and variable irrigation diversions, the set of measurements made on August 23 are inconclusive relative to actual losses in the streambed, but they reinforce the need for continuous monitoring at diversion points to balance outflow during periods of increased inflow from the Mapleton-Springville Lateral pipeline.

\section{October 11, 2016}

Discharge measurements were made in Hobble Creek at sites HC3 and HC6. Five discharge measurements were made at site $\mathrm{HC} 3$, which averaged $5.0 \mathrm{ft}^{3} / \mathrm{s}$ (table 2). Five measurements also were made in Hobble Creek at site HC6, which averaged $14.3 \mathrm{ft}^{3} / \mathrm{s}$. Discharge measurements at sites HC3 and HC6 showed a total increase in flow of $9.3 \mathrm{ft}^{3} / \mathrm{s}$ along the study reach. This was the largest increase in flow measured during the study. The larger increase is due in part, to inflow from the Mapleton City secondary irrigation system, which discharges substantially less or no water to Hobble Creek during the irrigation season. There was an increase of $5.7 \mathrm{ft}^{3} / \mathrm{s}$ in flow between sites HC3 and HC5 (a reach that includes Mapleton City secondary inflow). An additional increase of $3.6 \mathrm{ft}^{3} / \mathrm{s}$ was measured between sites HC5 and HC6. This increase is partly due to inflow from Wheeler Spring and water being diverted into the Island Ditch above site HC3 that was returning to the stream in this reach. A planned $10 \mathrm{ft}^{3} / \mathrm{s}$ pulse from the Mapleton-Springville Lateral pipeline and subsequent discharge measurements were not done because of the substantial variation in flow from the Mapleton City secondary inflow.

\section{November 7-9, 2016}

The last set of measurements in Hobble Creek was conducted during November 7-9. This set of measurements included a planned increase in streamflow (a pulse) of approximately $9-10 \mathrm{ft}^{3} / \mathrm{s}$ from the Mapleton-Springville Lateral pipeline. Initial measurements made at the head and tail of the primary study reach (sites $\mathrm{HC} 3$ and $\mathrm{HC} 6$, respectively) prior to the pulse showed an average flow of $9.4 \mathrm{ft}^{3} / \mathrm{s}$ at site $\mathrm{HC} 3$ and an average flow of $15.5 \mathrm{ft}^{3} / \mathrm{s}$ at site HC6 (table 4, fig. 3), for an average increase in flow between the sites of $6.1 \mathrm{ft}^{3} / \mathrm{s}$ (table 2). After the pulse was initiated at 12:30 p.m. on November 7, flow at site $\mathrm{HC} 3$ increased by $9.6 \mathrm{ft}^{3} / \mathrm{s}$ to $19.0 \mathrm{ft}^{3} / \mathrm{s}$, and flow at site HC6 increased by $9.9 \mathrm{ft}^{3} / \mathrm{s}$ to $25.4 \mathrm{ft}^{3} / \mathrm{s}$ (table 4 ). The pulse was terminated at 10:30 a.m. on November 9. Subsequent measurements indicated that flow at site $\mathrm{HC} 3$ had decreased by $9.7 \mathrm{ft}^{3} / \mathrm{s}$ from the pulse flow to an average flow of $9.3 \mathrm{ft}^{3} / \mathrm{s}$, and flow at site HC6 had decreased by $9.8 \mathrm{ft}^{3} / \mathrm{s}$ to an average flow of $15.6 \mathrm{ft}^{3} / \mathrm{s}$ (table 4). The average change in discharge at site $\mathrm{HC} 3$ relative to an increase in flow from the MapletonSpringville Lateral pipeline (the pulse) was $9.6 \mathrm{ft}^{3} / \mathrm{s}$, and the average change at site $\mathrm{HC} 6$ was about $9.8 \mathrm{ft}^{3} / \mathrm{s}$. On the basis of these measurements it appears that all of the flow measured at site $\mathrm{HC} 3$ from the pulse was accounted for at site HC6 using comparative instantaneous measurements.

U.S. Geological Survey gaging station 10153100 (site HC8, about 3.7 mi downstream of site HC6; fig. 1) has a continuous discharge record for the time period associated with this study. Prior to the pulse the flow at this site was $14 \mathrm{ft}^{3} / \mathrm{s}$. During the pulse the flow increased by $9.5 \mathrm{ft}^{3} / \mathrm{s}$ and averaged about $23.5 \mathrm{ft}^{3} / \mathrm{s}$ (fig. 3). This change appears slightly smaller than the change associated with the pulse at sites HC3 and HC6, but statistically the same, indicating that for the conditions that existed during this part of the study there was no loss in flow relative to the pulse between the inflow at the Mapleton-Springville Lateral pipeline and the USGS gage 6.4 mi downstream.

During the November investigation stream stage was monitored and recorded at 15-minute intervals at sites $\mathrm{HC} 3$ and $\mathrm{HC} 8$ (stream stage data were not available at site HC6 for this period). A stage/discharge relation was developed using the instantaneous measurements of stage and discharge (data available on NWISWeb at https://waterdata.usgs.gov/ ut/nwis/measurements). This relation was used to calculate the discharge shown on figure 3 . A baseline discharge was determined from values prior to and after the pulse. This baseline discharge was subtracted from the total discharge during the pulse, and the net streamflow volume associated with the pulse (shown as the shaded areas on figure 3) was determined. For the November investigation the theoretical streamflow volume associated with the pulse was 36.1 acre-ft $\left(9.5 \mathrm{ft}^{3} / \mathrm{s}\right.$ for 46 hours). The calculated value for streamflow volume associated with the pulse at site $\mathrm{HC} 3$ was 36.6 acre-ft, and the calculated value at site HC8 was 35.1 acre-ft. The calculated values are 101 and 97 percent, respectively, of the theoretical value. Because the calculations of discharge used in this study 

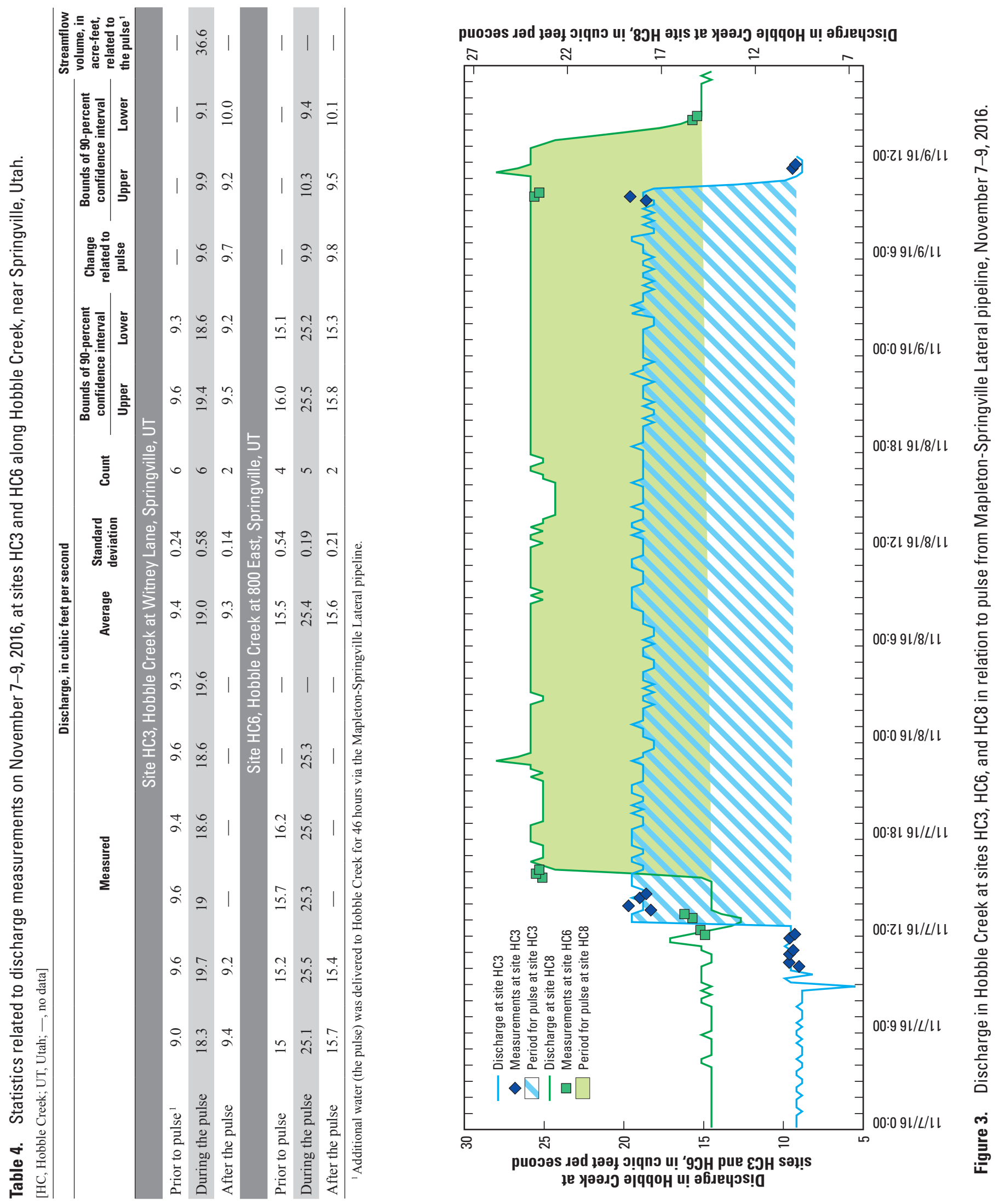
are generally plus or minus 5 percent, there is no significant difference between the theoretical streamflow volume and the calculated streamflow volume at sites $\mathrm{HC} 3$ and $\mathrm{HC} 8$ associated with the pulse that would indicate water was being lost.

During the November streamflow investigation, diversion gates were not adjusted, and inflow from springs and drains was relatively constant. However, measurements of discharge at intermediate sites along Hobble Creek showed that water was being diverted into ditches and then returning to the stream. Measurements at site HC4 (table 5) showed that about $1.8 \mathrm{ft}^{3} / \mathrm{s}$ were lost between sites $\mathrm{HC} 3$ and $\mathrm{HC} 4$ prior to the pulse and that about $2.5 \mathrm{ft}^{3} / \mathrm{s}$ were lost during the pulse. This indicates that substantial and variable amounts of flow were probably being diverted into the Sage Creek Ditch. It was noted that a Sage Creek Ditch overflow immediately downstream of site $\mathrm{HC} 4$ was actively discharging to the stream. Additionally, measurements at the Sage Creek Ditch weir indicated flow prior to the pulse was less than $0.1 \mathrm{ft}^{3} / \mathrm{s}$ and $0.46 \mathrm{ft}^{3} / \mathrm{s}$ during the pulse - all of which returned to the stream. Measurements of flow at intermediate site HC5 prior to the pulse $\left(14.9 \mathrm{ft}^{3} / \mathrm{s}\right)$ showed additional inflow that resulted in an increase of about $5.4 \mathrm{ft}^{3} / \mathrm{s}$ in the reach between $\mathrm{HC} 3$ and
HC5 (table 5). Of this, approximately $3.3 \mathrm{ft}^{3} / \mathrm{s}$ were being discharged from the Mapleton City secondary inflow (Mark Breitenbach, Central Utah Water Conservancy District, written commun., November 16, 2016). During the pulse, measurements at site $\mathrm{HC} 5$ (average of $24.6 \mathrm{ft}^{3} / \mathrm{s}$ ) showed an increase in flow of about $5.6 \mathrm{ft}^{3} / \mathrm{s}$ in the reach between sites $\mathrm{HC} 3$ and HC5. Prior to and during the pulse, measurements showed an increase in flow in the reach between sites HC5 and HC6 of 0.6 and $0.8 \mathrm{ft}^{3} / \mathrm{s}$, respectively. The increase in flow in this reach includes inflow from Wheeler Spring and from the Springville High School drain.

Three measurements of discharge were made at site HC7, which is immediately downstream of Swenson Dam and the primary study reach. One measurement prior to the pulse and two during the pulse, showed streamflow losses in Hobble Creek of 4.3 and $4.1 \mathrm{ft}^{3} / \mathrm{s}$, respectively (table 5). These losses are probably associated with the ditch diversions at the Swenson Dam. As stated earlier, the additional water associated with the pulse was accounted for at site HC8, so water diverted at headgates downstream of site HC6 apparently returned to the stream prior to site $\mathrm{HC} 8$.

Table 5. Discharge measured on November 7-9, 2016, at sites along Hobble Creek, near Springville, Utah.

[HC, Hobble Creek; \#, number; -, no data]

\begin{tabular}{|c|c|c|c|c|c|}
\hline \multirow{3}{*}{ Site } & \multicolumn{5}{|c|}{ Discharge, in cubic feet per second } \\
\hline & \multicolumn{2}{|c|}{ Prior to pulse ${ }^{1}$} & \multicolumn{3}{|c|}{ During the pulse } \\
\hline & Measurement \#1 & Average & Measurement \#1 & Measurement \#2 & Average \\
\hline $\mathrm{HC} 3^{2}$ & - & 9.5 & - & - & 19.0 \\
\hline $\mathrm{HC} 4$ & 7.7 & 7.7 & 16.9 & 16.1 & 16.5 \\
\hline HC5 & 14.9 & 14.9 & 25 & 24.3 & 24.6 \\
\hline $\mathrm{HC}^{2}$ & - & 15.5 & - & - & 25.4 \\
\hline $\mathrm{HC} 7$ & 11.2 & 11.2 & 20.5 & 22.1 & 21.3 \\
\hline
\end{tabular}

${ }^{1}$ Additional water (the pulse) was delivered to Hobble Creek for 46 hours, starting November 7 and ending November 9, via the Mapleton-Springville Lateral pipeline.

${ }^{2}$ Individual measurements made at sites HC3 and HC6 are shown in table 4. 


\section{Summary}

The Central Utah Water Conservancy District (CUWCD) is proposing to deliver supplemental water to Hobble Creek from Strawberry Reservoir through the Mapleton-Springville Lateral pipeline. A substantial portion of the supplemental water is intended to benefit June Sucker recovery and other fish and wildlife along Hobble Creek. The objective of this study was to determine stream gains or losses along a section of Hobble Creek between the Island Dam and the Swenson Dam (the primary study reach) during different seasons and flow conditions.

Paired measurements of flow in Hobble Creek consistently showed an overall increase in flow in the primary study reach between sites $\mathrm{HC} 3$ and HC6. Five sets of paired measurements made from June to November 2016, indicated these flow increases ranged from $6.1 \mathrm{ft}^{3} / \mathrm{s}$ to $9.3 \mathrm{ft}^{3} / \mathrm{s}$. The increases in flow in this reach are generally from groundwater inflow from springs, drains, and other dispersed seepage; however, during the non-irrigation season additional water is often discharged from the Mapleton City secondary system into Hobble Creek at site $\mathrm{HC} 4$.

During August and November, two sets of measurements were made at several locations along the study reach to document baseline conditions, and then an additional amount of water (a pulse of about $9-10 \mathrm{ft}^{3} / \mathrm{s}$ designed to simulate the supplemental flow proposed by CUWCD) from Strawberry Reservoir through the Mapleton-Springville Lateral pipeline was added to the reach. Subsequent measurements were made throughout the reach to quantify gains and losses associated with the pulse. During the August 23 measurements, the average change at the upstream site (HC3) relative to the pulse was $9.3 \mathrm{ft}^{3} / \mathrm{s}$, and the average change at the downstream site (HC6) was about $8.4 \mathrm{ft}^{3} / \mathrm{s}$. On the basis of these measurements it appears that about $0.9 \mathrm{ft}^{3} / \mathrm{s}$ of the pulse measured at site $\mathrm{HC} 3$ was not measured at site HC6. However, there was no significant difference between the theoretical streamflow volume and the calculated streamflow volume at sites HC3 and HC6 associated with the pulse that would indicate water was being lost. Because of substantial and variable irrigation diversions, the set of measurements made on August 23 are inconclusive relative to actual seepage in the streambed.

During the November 7-9 streamflow measurements, the average change in discharge at site $\mathrm{HC} 3$ relative to an increase in flow from the Mapleton-Springville Lateral pipeline (the pulse) was $9.6 \mathrm{ft}^{3} / \mathrm{s}$, and the average change at site HC6 was about $9.8 \mathrm{ft}^{3} / \mathrm{s}$. On the basis of these measurements it appears that flow associated with the pulse at site $\mathrm{HC} 3$ was accounted for at site HC6.

U.S. Geological Survey gaging station 10153100 (site HC8, about 3.7 mi downstream of site HC6) has a continuous discharge record for the time period associated with this streamflow study. Prior to the November pulse, the flow at this site was $14 \mathrm{ft}^{3} / \mathrm{s}$. During the pulse, the average flow was about $23.5 \mathrm{ft}^{3} / \mathrm{s}$ - an increase of $9.5 \mathrm{ft}^{3} / \mathrm{s}$ associated with the pulse. This value is slightly smaller than the change at sites
HC3 and HC6, but statistically the same, indicating that for the conditions that existed during this streamflow study there was no loss in flow relative to the pulse between the inflow at the Mapleton-Springville Lateral pipeline and the USGS gage $6.4 \mathrm{mi}$ downstream. Additionally, there was no significant difference between the theoretical streamflow volume and the calculated streamflow volume at sites $\mathrm{HC} 3$ and $\mathrm{HC} 8$ associated with the pulse that would indicate water was being lost.

Multiple sets of streamflow measurements made between June and November 2016, indicate that a reach of Hobble Creek between sites HC3 and HC6 is a gaining stream. Although there are multiple diversions and returns to the stream in this reach, supplemental water added to the stream will not be lost from the reach if diversions are carefully managed.

\section{References Cited}

Brooks, L.E., and Stolp, B.J., 1995, Hydrology of southern Utah and Goshen Valleys, Utah, and simulation of the ground-water system: Utah Department of Natural Resources Technical Publication No. 111, 96 p.

Turnipseed, D.P., and Sauer, V.B., 2010, Discharge measurements at gaging stations: U.S. Geological Survey Techniques and Methods, book 3, chap. A8, 87 p. [Also available at https://pubs.usgs.gov/tm/tm3-a8/].

U.S. Geological Survey, 2017, National Water Information System - Web interface: USGS water data for the nation, accessed December 12, 2016, at http://dx.doi.org/10.5066/ F7P55KJN.

Utah Reclamation Mitigation and Conservation Commission, 2009, Lower Hobble Creek ecosystem flow recommendations-Final report: Utah Reclamation Mitigation and Conservation Commission, Salt Lake City, Utah, accessed December 1, 2016, at https://www.mitigationcommission. gov/native/pdf/final_report_hobble_flows_apr09.pdf. 
Streamflow Investigations on a Reach of Hobble Creek Near Springville, Utah 



\section{$\frac{\mathbb{3}}{3}$}

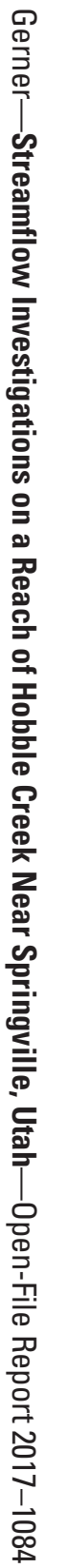

